\title{
Regional chemostratigraphic key horizons in the macrofossil-barren siliciclastic lower Miocene lacustrine sediments (Most Basin, Eger Graben, Czech Republic)
}

\author{
TOMÁŠ MATYS GRYGAR \& KAREL MACH
}

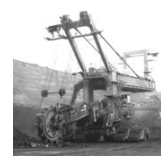

\begin{abstract}
Six sediment cores from two of four depocentres in the Most Basin, mostly consisting of macrofossil barren fluviodeltaic and lacustrine sediments of Holešice and Libkovice members of the Most Formation (lower Miocene, Burdigalian) were subjected to chemostratigraphic correlation, based on CEC and EDXRF proxy element analyses. CEC-step, prominent $\mathrm{K} / \mathrm{Al}$ minima and crandallite-bearing horizons in monotonous lacustrine mudstones of the Libkovice Member provide several local isochronous or nearly isochronous key horizons, which we propose for a basin-scale correlation of the upper Most Basin sediment fill. These key horizons prove a spatially uniform sedimentary environment in a single lake (original area $\sim 1,000 \mathrm{~km}^{2}$ ) during deposition of a considerable part of the siliciclastics overlying the main coal seam that tops the lower basin fill. We propose the CEC-step horizon as a novel boundary between Holešice and Libkovice members, i.e. the conversion of previously formal lithostratigraphic units to members with an isochronous boundary. That boundary together with recent sedimentological studies would assign Břeštany clay to the top of the Holešice Member. The upper boundary of the Libkovice Member could be the sediment coarsening related to a lake level decrease before deposition of Lom coal seam. The study will allow progress in palaeogeographic and palaeoenviromental reconstruction of the lower Miocene in the Most Basin. The proxy analyses (CEC vs Al/Si ratios) allow reliable numeric differentiation between kaolinite-rich, smectite-poor and smectite-rich clay assemblages in Holešice and Libkovice members. The plots of CEC vs $\mathrm{Al} / \mathrm{Si}$ ratios should be applicable for fingerprinting any other monotonous lacustrine clastics with variable mineralogy of the clay assemblage. $\bullet$ Key words: Most Basin, Burdigalian, chemostratigraphy, proxy analyses, lacustrine sediments.
\end{abstract}

\begin{abstract}
MATYS GRYGAR, T. \& MACH, K. 2013. Regional chemostratigraphic key horizons in the macrofossil-barren siliciclastic lower Miocene lacustrine sediments (Most Basin, Eger Graben, Czech Republic). Bulletin of Geosciences 88(3), 557-571 (9 figures, 3 tables). Czech Geological Survey, Prague. ISSN 1214-1119. Manuscript received June 25, 2012; accepted in revised form September 24, 2012; published online January 17, 2013; issued July 3, 2013.
\end{abstract}

Tomáš Matys Grygar, Institute of Inorganic Chemistry AS CR, v.v.i., 25001 Řež, Czech Republic, grygar@iic.cas.cz. Karel Mach, Severočeské doly, a.s., 5. května, 41801 Bílina, Czech Republic; mach@sdas.cz.

The Most Basin (Fig. 1) is a valuable sedimentary archive of European continental environment during the lower Miocene, a period preceding the Middle Miocene Climatic Optimum (MMCO), which was followed by a continuous global climate cooling toward the Pleistocene. Seasonal distribution of precipitation and temperatures during the lower Miocene and the effect of the MMCO in European continental setting are a matter of debate and a subject of systematic reconstructions. Large lakes belong among the most reliable archives of pre-Quaternary climates (Parrish 1998). Sediments of an extensive lake represent a substantial part of the Most Basin sediment fill (Fig. 2), but yet they have not been utilised as palaeoenviromental archive, certainly because of apparent uniformity, palaeontological sterility, unclear stratigraphy and lack of dating points. The sequence hence remains a challenge for novel approaches.

The Most Basin has been subjected to an extensive geological research for more than a century. Apparent lack of correlation horizons in the Most Basin fill and doubts about isochronicity of the coal formation (Hokr 1982, Elznic et al. 1998) have hindered correlation of previous formal lithostratigraphic schemes for the different parts of the basin. Recent research in the Most Basin has included palaeobotany with environmental interpretations (Kvaček 1998, Kvaček et al. 2004, Teodoridis \& Kvaček 2006, Teodoridis 2010, Teodoridis et al. 2011), sedimentology of fluvial and fluviodeltaic systems (Rajchl \& Uličný 2005, Rajchl et al. 2008) and basin development (Rajchl et al. 2009), correlation of the main coal seam by geophysical logs 
(Mach 1997) and analysis of sulphur stable isotopes (Mach et al. 1999). A missing local stratigraphic frame for these studies is hence an obstacle, which hinders integration of that research and its palaeonvironmental interpretation. Otherwise quite detailed palaeogeographic reconstruction of the basin development (e.g., Mach 1997, Elznic et al. 1998, Mach 2010) also needs a progress by introducing more correlation horizons to cover the broadest possible thickness of the basin fill. Unfortunately, detailed biostratigraphic zonation and direct dating are not accessible in the Most Basin. In such situation, chemostratigraphy could be very helpful, particularly if it can identify correlation horizons.

Previous research pointed to two possible local horizons in the basin. A crandallite bearing horizon was found in Tušimice area (Novák et al. 1993, Coufal \& Mejstř́iková 1996) and attributed to products of volcaniclastic fallout/wash to the lake, however. Very similar horizons were identified in 1997 in other open cast localities (two in Bílina mine, one in VČSA mine) by $\mathrm{K}$. Mach and Z. Dvořák (unpublished results), but there was no evidence for their stratigraphic significance due to a long distance between individual open casts, no additional markers and a considerable similarity of individual layers in one opencast mine. Furthermore, a change in the clay-mineral assemblage, namely the increase of a smectite percentage, was identified in the so-called Koh-i-noor borehole lines in the Bílina and Most areas (central part of the basin) within the fine lacustrine sediments (Rákosová 1982, Sloupská 1985). That change has also been known to field geologists from Bílina, Libouš and VČSA open cast mines, because it is important feature of possible raw materials for production of ceramics and it also affects the mechanic properties of the overburden. Actually these facts yet unpublished in international scientific journals have motivated our here presented research.

The aim of this paper is to improve the stratigraphic scheme for the Most Formation on the base of critical evaluation of traditional models, new sedimentological research and our novel geochemical analyses. The lacustrine sediments above the main coal seam in the Most Basin are a valuable palaeoenvironmental archive, of which value has not been adequately utilised.

\section{Geological setting and methods}

\section{Geological setting and depositional environment}

The Most Basin is a part of the European Cenozoic Rift System (Kopecký 1978, Ziegler \& Dèzes 2007, Rajchl et al. 2009). In the past century its study has mainly been motivated by coal mining (Pešek et al. 2010 and references therein) and later also by search for clay sources (Rákosová
1982, Sloupská 1985). Several mostly formal lithostratigraphic systems were developed for practical needs of mining (Hurník \& Marek 1962, Elznic 1968, Elznic 1973, Domácí 1975, Hokr 1982, Malkovský et al. 1985, Váně 1987, Hurník 2001, Pešek et al. 2010 and references therein). For the stratigraphic assignment we use a lithostratigraphic scheme proposed by Domácí (1975), adopted by Mach (2003) and recently used by Rajchl et al. (2008); this scheme was further elaborated according to our new findings and it is shown in Fig. 2.

The Most Basin (Fig. 1) is the largest of four basins within the Eger Graben in the Czech Republic. Its area is about $1400 \mathrm{~km}^{2}$ (Rajchl et al. 2009) and the basin fill remnants are preserved at the area of $870 \mathrm{~km}^{2}$ (Kvaček et al. 2004). The maximal total thickness of the preserved basin fill is up to $500 \mathrm{~m}$. Four depocentres are distinguished in the basin (Rajchl et al. 2009). Two of four depocentres, Bílina (B) and Chomutov $(\mathrm{CH})$, were subjected to our study (Fig. 1), because the drill coring is still performed by coal mines there. In the final stage of the syn-rift development (Rajchl et al. 2009) several hundred meters thick siliciclastic sediments were deposited above the main coal seam. The basin sediment fill was originally thicker, but up to $300 \mathrm{~m}$ of sediments was removed by erosion (Hurník 1978).

The age constraints for that fluvial, fluviodeltaic and lacustrine clastics were reviewed by Kvaček et al. (2004), Teodoridis \& Kvaček (2006) and Rajchl et al. (2009). According to them, the studied deposits (Holešice and Libkovice members) were formed mainly in the Burdigalian, maybe in its later part, in any case in the Early Miocene.

Understanding to palaeogeography development should help to identify temporal relations between local lithological units in the basin. Combination of previous results from geological survey, analyses of fault structure, gravity gradients and seismic profiles allowed Rajchl et al. (2009) to divide the basin subsidence into 4 intervals. They assumed that the basin subsidence started by development of local faults which allowed formation and spreading of peatlands and temporal water bodies over the basin floor in interval 2. Merging local faults and fastening subsidence in the interval 3 produced an entire basin swamp and finally a large lake in interval 4 , the last interval of the syn-rift sedimentation. During the main peat swamp period the basin was mostly supplied by water and clastics from the "central river" (Pešek \& Spudil 1986), which changed its inlet to the basin between Žatec "delta" (Žatec fluvial system) and Bílina delta, and also by several local streams. The deltas of tributaries of the lake in its largest spatial extent (a whole basinal Libkovice lake) had not been identified; obviously the deltas were outside the preserved basin fill deposits. Corresponding monotonous, nearly fossil-barren lacustrine deposits in the Most Formation above the main coal seam are 150-200 m thick. Such sediments seem to be an optimal subject for a chemostratigraphic correlation (Nichols 1999). 


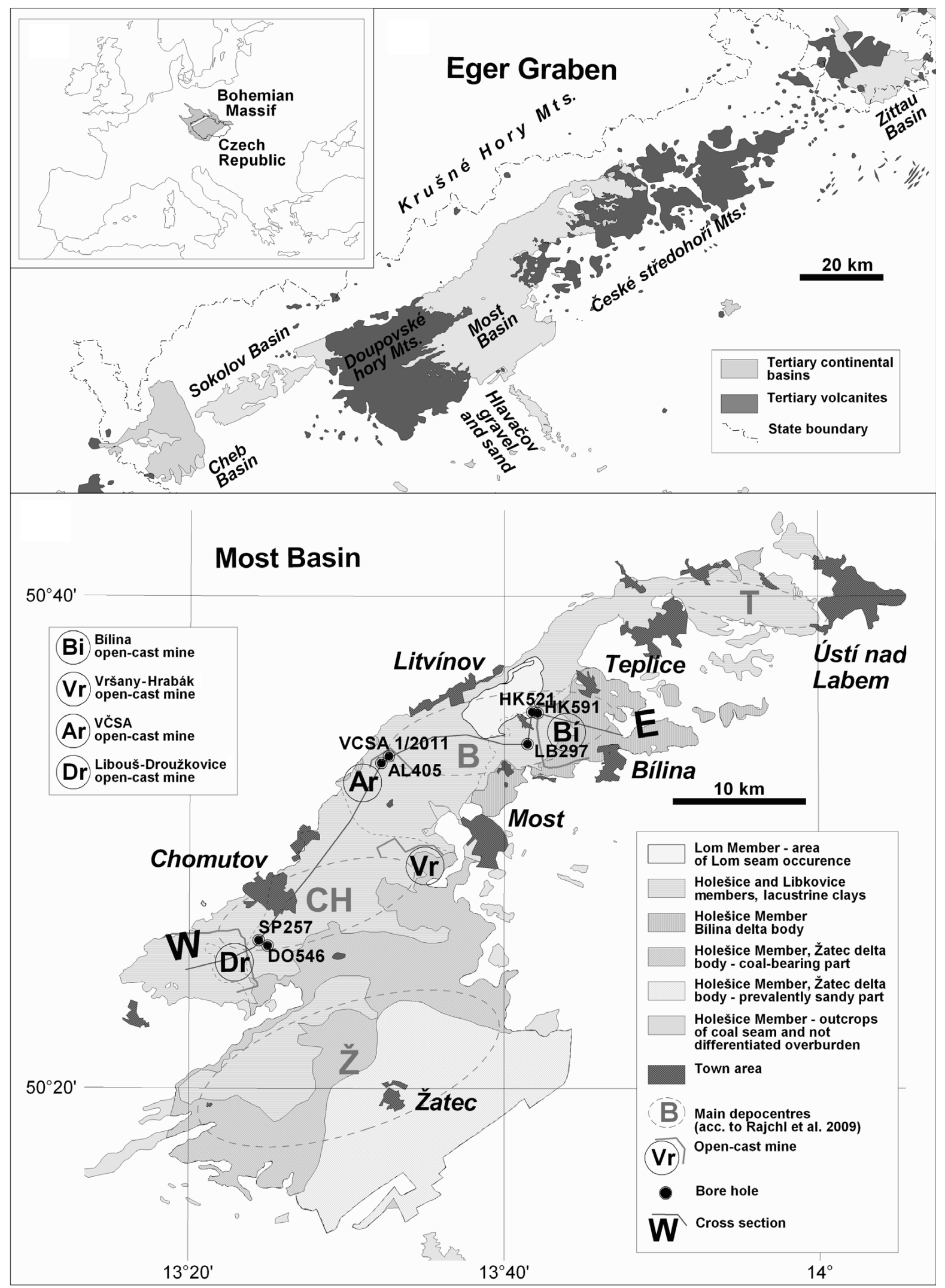

Figure 1. Location of Bohemian Massif in Europe (A), map of the Eger Graben (B) and detailed map of the Most Basin with the location of cores (C). Abbreviations of the depocentres: T - Teplice, B - Bílina, Ž - Žatec, $\mathrm{CH}$ - Chomutov. 


\section{Most Basin fill stratigraphy}

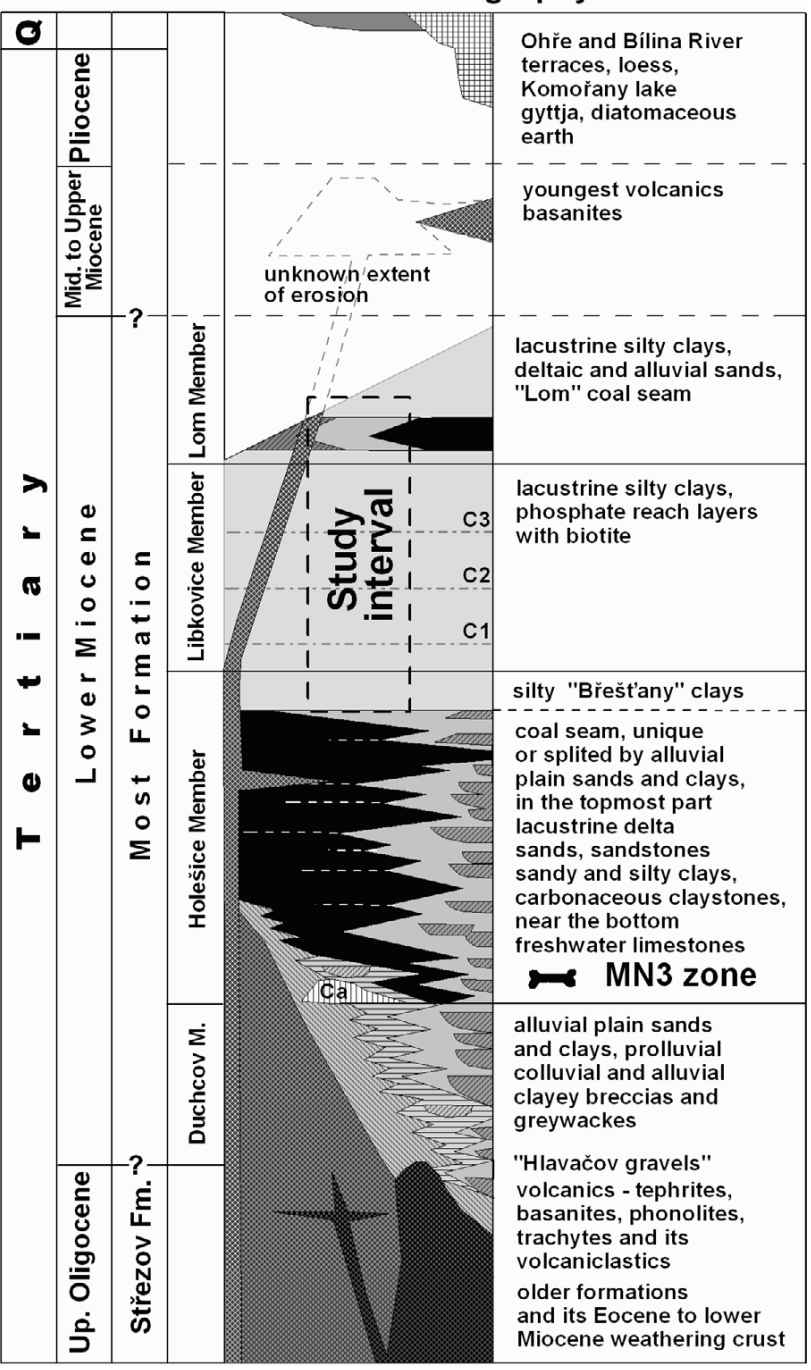

Figure 2. Stratigraphic scheme for the Most Basin fill proposed by Domácí (1975) and further developed by Mach (2003) and Rajchl et al. (2008). The stratigraphic assignment of Břeštany clay to Holešice Member and existence of $\mathrm{C} 1$ to $\mathrm{C} 3$ horizons in Libkovice Member are new results presented in this paper.

\section{Sampling}

The cores were obtained in the frame of geological survey by mining companies Severočeské doly, a.s. and Litvínovská uhelná, a.s. Lithological description and sediment sampling from the cores was performed by authors of this paper and geologists from the coal mining companies in the period 2009-2011. The list of cores is in Table 1. The chemostratigraphic correlation in monotonous Libkovice Lake mudstones has required laboratory analysis of relatively densely sampled sediment cores (3-5 samples/m). To manage this task at reasonable costs, we used two simple proxy analyses: X-ray fluorescence analysis in the simplest laboratory setup (sample manual powdering and pouring into measuring cells) and cation exchange capacity determination by $[\mathrm{Cu} \text { (trien) }]^{2+}$ complex.

Due to complete destruction of its original locality at Bílina mine in the last 40 years by mining of the sequences that overlaid the coal seams, samples of the facies called Břeštany clays had to be obtained from paleontological collections of Regional Museum Most, Regional Museum Teplice and Senckenberg Naturhistorischen Sammlungen Dresden. Small (analytical) samples were obtained by cutting from individual palaeontologically described samples.

\section{Analytical techniques}

Samples from the cores were air dried, manually ground in agate mortars and subjected to laboratory analyses without further treatment. Element analysis by energy disperse $\mathrm{X}$-ray fluorescence (EDXRF) analysis was performed with direct analysis of manually ground sediments similarly as in our previous studies (Lojka et al. 2009, Grygar et al. 2010) using MiniPal 4.0 (PANalytical, the Netherlands) with Rh lamp and Peltier cooled Si PIN detector. The obtained EDXRF signals (in counts per second, c.p.s.) were calibrated by control analyses of 32 samples in the accredited analytical laboratory of the Nanotechnological Centre, VŠB - Technical University Ostrava using a conventional quantitative analysis after fusing samples with lithium tetraborate and analysis by X-ray spectrometer SPECTRO XEPOS (SPECTRO A.I. GmbH, Germany) with Pd X-ray tube $(50 \mathrm{~W})$. The selected results of calibration are listed in Table 2.

Cation exchange capacity (CEC) was determined by ion exchange with $[\mathrm{Cu}(\text { trien })]^{2+}$ (Meier \& Kahr 1999) using methodology optimized for the analysis of sediments (Grygar et al. 2009, 2010; Lojka et al. 2009). The method is based on determination of the decrease of the concentration of the $[\mathrm{Cu}(\text { trien })]^{2+}$ ions from solution in contact with 100-900 mg sediment by atomic absorption spectroscopy. This approach is suitable for processing large sample series by a routine laboratory analytical procedure; it is more suitable for semiquantitative analysis of expandable clay minerals than conventional X-ray diffraction and moreover it does not require separation of the clay size fraction from the analysed samples.

\section{Results}

\section{Lithology of the studied sequences}

Lithological description of the cores is shown in Figs 3 and 4. The main coal seam is represented by coal and clayey coal in the basal part of all long cores. It is overlain 
Table 1. List of studied cores and a section. Position of cores, depocentres, mines and sites in Fig. 1.

\begin{tabular}{|c|c|c|c|c|c|}
\hline Core/profile & Depocentre & Mine & Site & Total length (m) & $\begin{array}{l}\text { Thickness of the siliciclastics of the Most Formation } \\
\text { above the coal seam }(\mathrm{m})\end{array}$ \\
\hline LB297 & $\mathrm{B}$ & Bílina & Libkovice & 289.0 & 251 (including Bílina Delta) \\
\hline HK521 & B & Bílina & Hrdlovka & 251.4 & 246 (including Lom Mb.) \\
\hline HK591 & B & Bílina & Hrdlovka & 255.7 & 219 \\
\hline AL405 & B & VČSA & Albrechtice No. Most & 94.0 & 63 \\
\hline VČSA1/2011 & B & VČSA & Albrechtice No. Most & 11.0 & \\
\hline SP257 & $\mathrm{CH}$ & Libouš-Droužkovice & Spořice & 164.0 & 123 \\
\hline DO546 & $\mathrm{CH}$ & Libouš-Droužkovice & Droužkovice & 162.5 & 105 \\
\hline
\end{tabular}

by mudstones in both Chomutov and Bílina depocentres. In the Chomutov depocentre and the western part of the Bílina depocentre (VČSA area), the mudstones above the main coal seam are monotonous silty clays, which cannot be further differentiated on the base of their appearance.

In the Bílina area (the eastern part of the Bílina depocentre), lithology above the main coal seam is more variable. The mudstones just above the coal seam are occasionally laminated (e.g. in LB297). In the easternmost part of the Bílina depocentre the Bílina delta clastics suppressed or prevented coal formation (Fig. 1). The Bílina delta heteroliths are laminated mudstones, siltstones or fine to coarse sands, occasionally with thin intercalations of coaly clays. The heteroliths are overlaid by monotonous lacustrine mudstones conventionally assigned to Libkovice Member. In the Bílina area, Břeštany clay, fine mudstones with occasional siderite cementation and common plant fossils, are found at the boundary between the Holešice and Libkovice members.

Crandallite-bearing horizons were identified in walls created by overburden mining of the clastic sequences that overlaid the coal seams thank to their fragile break up and a different way of weathering in the comparison with surrounding clay strata. They are rarely identified in drill cores due their low colour and textural contrasts, fragility, small thickness and consequent easy destruction during the drilling. Small thickness of the crandallite-bearing layers and their weak geophysical contrast did not allow to find any connection between their occurrence and well logs in the boreholes. We succeeded to identify two crandallite-bearing horizons in the cores of HK591 borehole, one in LB297 (Fig. 3) and two in DO546 (Fig. 4).

\section{$\mathrm{K}$ and $\mathrm{Ti}$ element signatures and crandallite-bearing horizons}

The contents of two elements, $\mathrm{K}$ and $\mathrm{Ti}$, show remarkable relation to the stratigraphic position in the analysed cores. The clastics below the main coal seams in all cores have much lower $\mathrm{K} / \mathrm{Al}$ and usually higher $\mathrm{Ti} / \mathrm{Al}$ ratios than the
Table 2. Conditions for proxy analysis of $\mathrm{Al}, \mathrm{Si}, \mathrm{K}$ and $\mathrm{Ti}$ and calibrations of the obtained element ratios.

\begin{tabular}{lll}
\hline Elements & $\begin{array}{l}\text { Conditions } \\
\text { of proxy analyses }\end{array}$ & $\begin{array}{l}\text { Calibration curves for recalculation } \\
\text { of proxy element ratios to real mass } \\
\text { fractions }\end{array}$ \\
\hline $\mathrm{Al}, \mathrm{Si}$ & $\begin{array}{l}4 \mathrm{kV} / 200 \mu \mathrm{A}, \mathrm{Kapton} \\
\text { filter, He flush }\end{array}$ & $\mathrm{Al} / \mathrm{Si}=2.33^{*}(\mathrm{Al} / \mathrm{Si})_{\text {proxy }}, \mathrm{R}^{2}=0.9036$ \\
$\mathrm{~K}, \mathrm{Ti}$ & $12 \mathrm{kV} / 100 \mu \mathrm{A}$, & $\mathrm{K} / \mathrm{Al}=0.0072^{*}(\mathrm{~K} / \mathrm{Al})_{\text {proxy }}-0.017$, \\
& $\mathrm{Al}$ filter & $\mathrm{R}^{2}=0.6593$ \\
& & $\mathrm{Ti} / \mathrm{Al}=0.0048^{*}(\mathrm{Ti} / \mathrm{Al})_{\text {proxy }}-0.027$, \\
& & $\mathrm{R}^{2}=0.7343$ \\
\hline
\end{tabular}

clastics above the seam. In the Bílina area the boundary between these Ti-rich and K-rich strata is within the lowash coal in the middle part of the main coal seam (in the middle bench); the boundary is up to several $\mathrm{m}$ thick. Its position is shown in Fig. 3. The plot of $\mathrm{K}$ versus $\mathrm{Ti}$ EDXRF signals (Fig. 5) clearly shows a remarkable contrast between these two types of the clastics.

The K-rich sediments above the main coal seam have much less pronounced element variations, but still they have a very characteristic pattern of the content of $\mathrm{K}$, which affords quite persuading correlation between the studied sediment cores. In Figs 3 and 4 the most prominent minima in $\mathrm{K} / \mathrm{Al} \operatorname{logs}$ are numbered by Roman numerals I to IV. The missing minimum IV in the Chomutov area (Fig. 4) is a consequence of erosional removal of the top of the lacustrine unit in the $\mathrm{W}$ part of the basin.

The crandallite-bearing horizons are located actually at the bottom of some of these prominent $\mathrm{K} / \mathrm{Al}$ minima, namely in I, III and IV minima. In Libouš-Droužkovice mine, where the thickness of the lower crandallite bearing layer exceeds $5 \mathrm{~cm}$, these horizons have been recognized earlier than in Bílina and VČSA mines, where the horizons are only $1-3 \mathrm{~cm}$ thick. Actually the knowledge on the position of K/Al minima helped us to focus on proper stratigraphic levels of the sediments in fields or drill cores and identify them. The crandallite-bearing horizons have substantially increased $\mathrm{Al}, \mathrm{Ca}, \mathrm{Sr}, \mathrm{Ba}$ and $\mathrm{P}$ signals in EDXRF measurement, which corresponds to the formula of Sr-rich crandallite (Dill 2001); it is Ca-Al phosphate with increased $\mathrm{Sr}$ and $\mathrm{Ba}$ contents. 


\section{HK521}
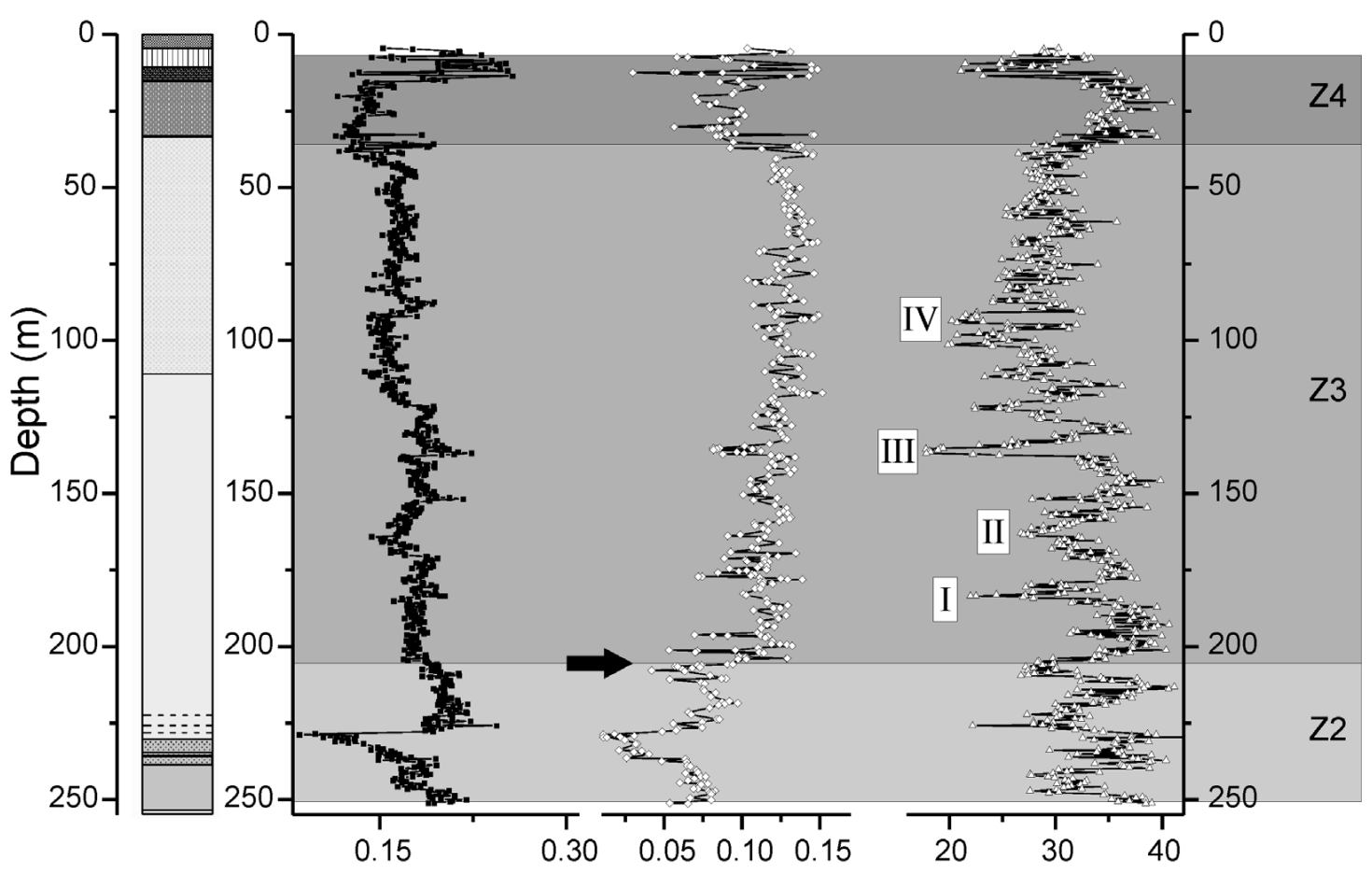

Lithology

$\mathrm{Al} / \mathrm{Si}$

$\Delta \mathrm{Cu}$ (signal ratio) $\quad(\mathrm{mmol} \mathrm{Cu} / \mathrm{g})$

$\mathrm{K} / \mathrm{Al}$

(signal ratio)

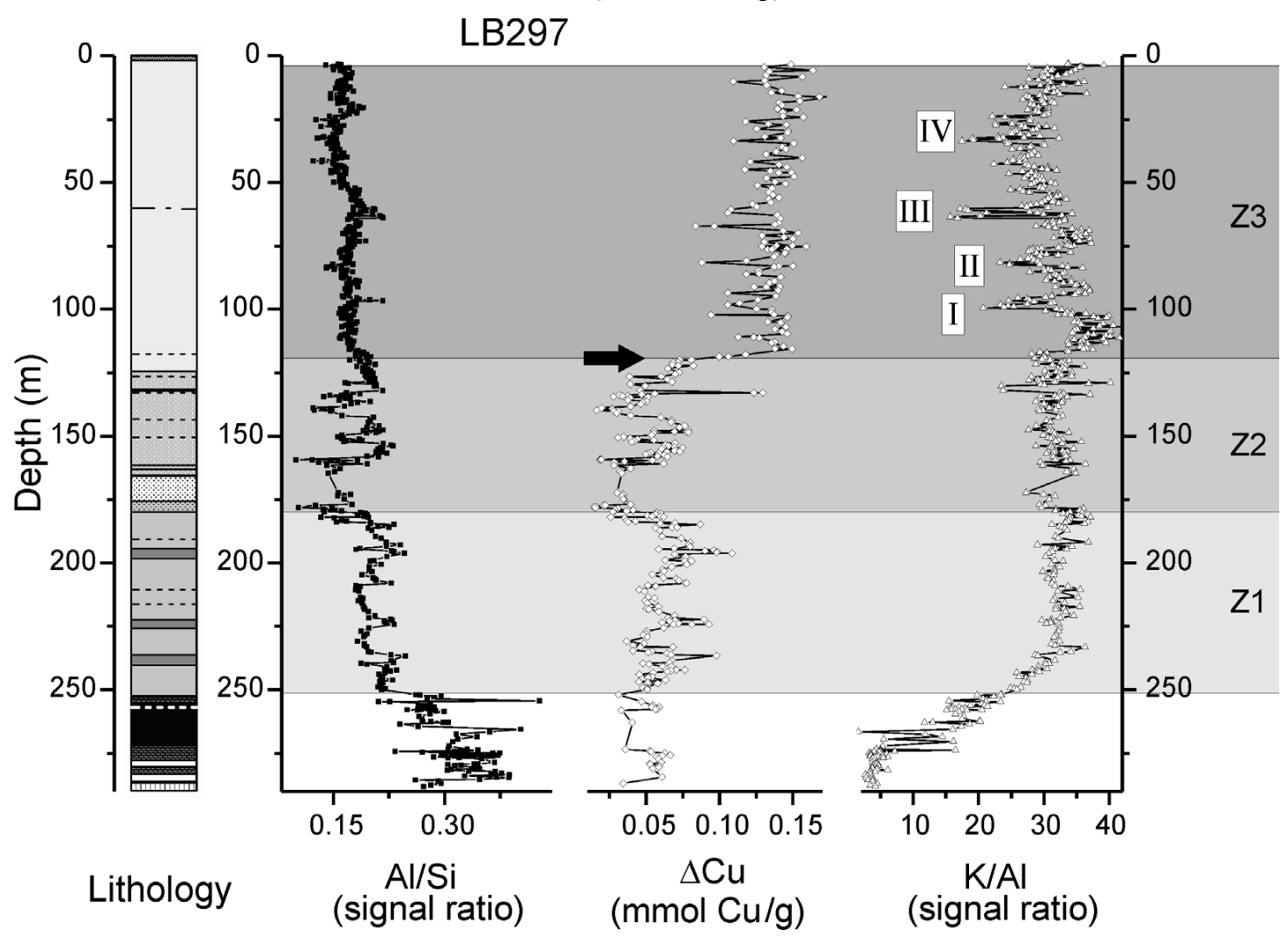

Figure 3. Cores LB297 and HK521 with selected proxies, indication of geochemical zones. Legend to lithology in Fig. 4. Prominent K/A1 minima are numbered I to IV, CEC step horizon is indicated by an arrow. 


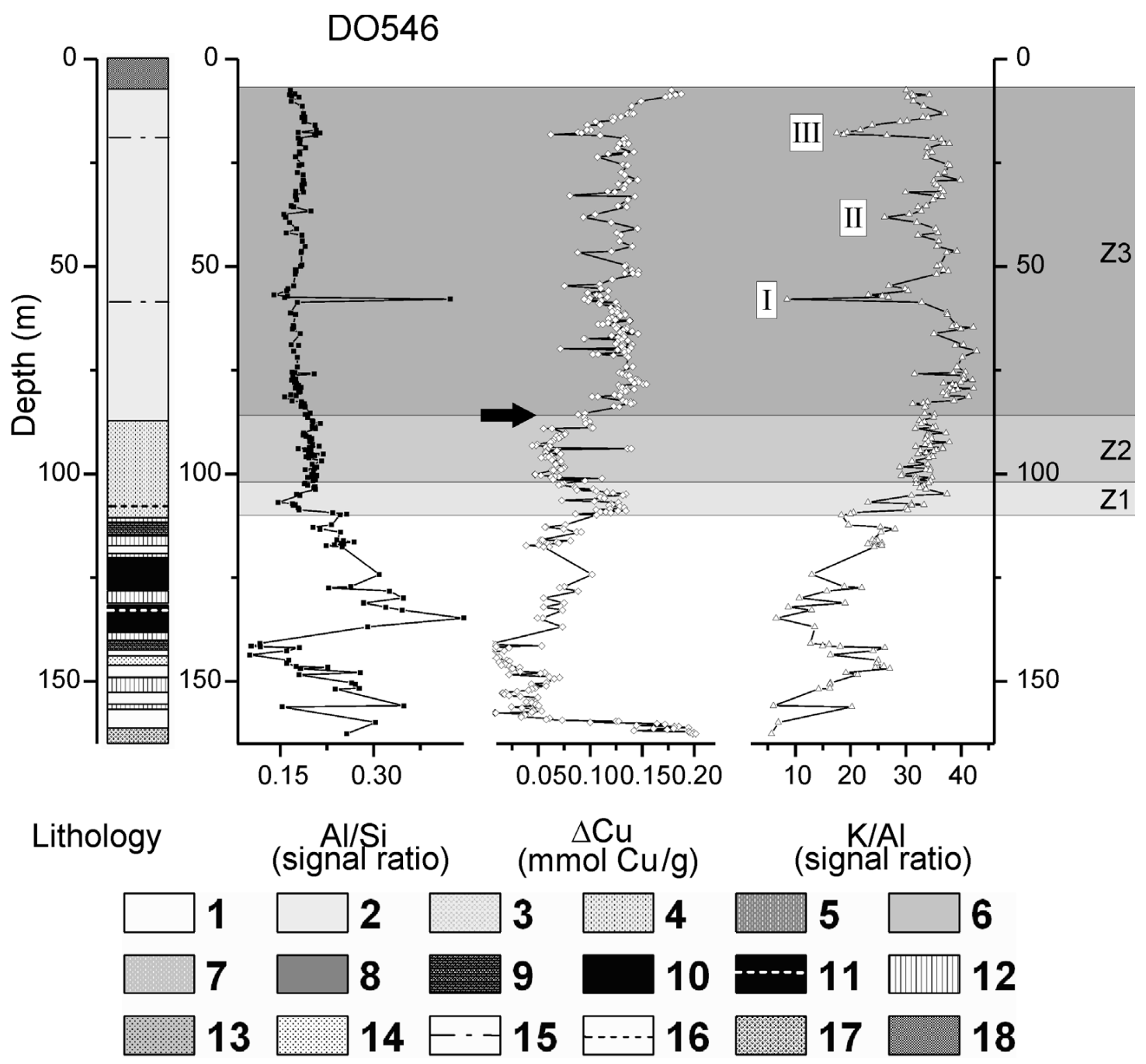

Figure 4. Core DO546 with selected proxies and indication of geochemical zones. Prominent K/Al minima are numbered I to III, CEC step horizon is indicated by an arrow. Legend to lithology and facies: 1 - white to brown-grey clay to sideritic claystone - fossil soils, 2 - grey monotonous lacustrine silty clays, 3 - grey monotonous lacustrine silty clays, clays with microscopic sulphides, 4 - grey monotonous lacustrine hard silty clays to claystones, 5 - green-grey monotonous lacustrine silty clays, 6 - grey layered prodeltaic silty clays, 7 - grey to green-grey silty to sandy delta plain clays, 8 - dark grey laminated prodeltaic to lacustrine silty clays, 9 - clayey coal, 10 - coal, 11 - prominent clayey partings within the coal seam, 12 - alternated coaly clay, coal and clay, 13 - layered prodeltaic sandy clays, 14 - deltaic to fluvial sands, 15 - phosphate layers, 16 - pelocarbonates, 17 - clays with tufitic admixture - fossil soils, 18 - quaternary soils, gravels.

\section{CEC analyses and $\mathrm{Al} / \mathrm{Si}$ ratio}

CEC patterns in the sediments above the main coal seam are very different in the two studied depocentres. This is particularly important for the first tens of metres above the main coal seam, as it is clear from the comparison of LB297 in the Bílina depocentre (Fig. 3) and DO546 in the Chomutov depocentre (Fig. 4). The CEC patterns allowed us to define sediment zones Z1 to Z3 for both depocentres (Table 3) and an additional zone Z4 in the Bílina depocentre, in the area where Lom Member sediments have been preserved (Fig. 1). Three groups of clastics according to the composition of their clay-mineral assemblage can be distinguished in the Most Basin using $\mathrm{CEC}$ and $\mathrm{Al} / \mathrm{Si}$ plot shown in Fig. 6. The qualitative mineral analysis of these three groups was already performed by a conventional X-ray diffraction analysis of clay fractions (Rákosová 1982, Sloupská 1985, Elznic et al. 1998 and references therein). Kaolinite-rich clay assemblage is typical of the highest $\mathrm{Al} / \mathrm{Si}$ ratio; that ratio can possibly be increased also by free Al oxides, which were found in some strata below the coal seam (Malkovský et al. 1985) and the lowest CEC values in Fig. 6. High $\mathrm{Al} / \mathrm{Si}$ and low $\mathrm{CEC}$ are in line with the formula and properties of kaolinite; in the Bílina depocentre that assemblage is typical of the clastics below the coal seam and for the bottom part of the seam. The group denoted as smectite-poor clay assemblage is a mixture of a clay size fraction with a variable percentage of coarse size 


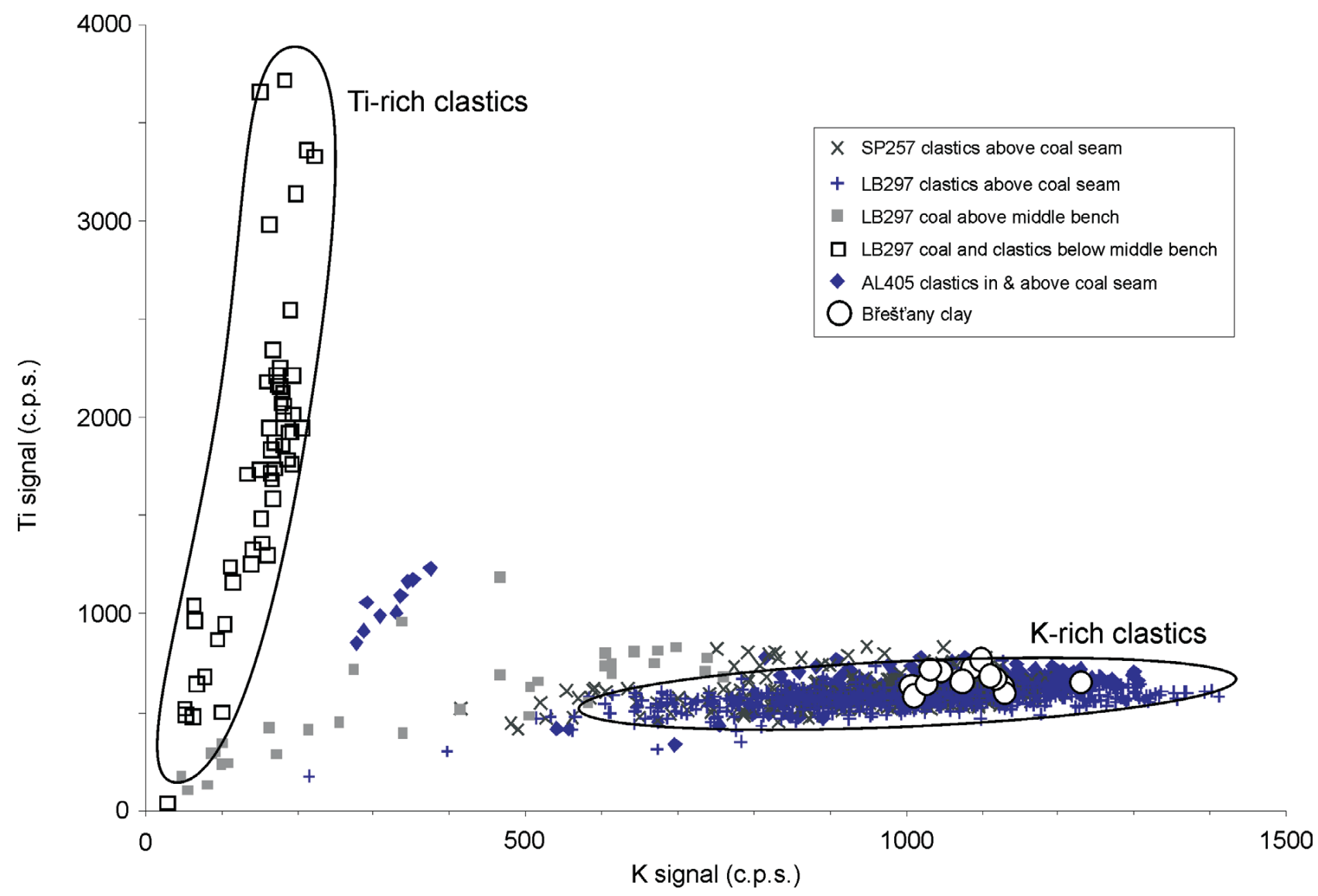

Figure 5. Plot of K and Ti signals for sediment samples from cores LB297, AL405 and SP257 and Břeštany clay. The sediments from long cores (LB297 and SP257) were divided according to the position with respect to the main coal seam.

fractions (silt and fine sand), that is indicated by a mixing line in Fig. 6. Clastics with smectite-rich clay assemblage are represented by a cluster of points with the highest CEC at moderate $\mathrm{Al} / \mathrm{Si}$ ratios.

The zones $\mathrm{Z} 1$ to $\mathrm{Z} 3$ defined by element signatures and CEC can be to a certain degree correlated with the local lithostratigraphy in the Bílina area (LB297, Fig. 3). Zone Z1 just above the coal seam coincides with a unit of mudstones, which are commonly laminated. Zone $\mathrm{Z} 2$ corresponds to the Bílina delta heteroliths, sediments of a river, which entered the basin via Bílina delta as it was described in detail by Dvořák \& Mach (1999) and Rajchl \& Uličný (2005). These heteroliths are capped by Břeštany clays, which also belong to the sediment unit Z2 with the smectite-poor clay assemblage. To confirm the assignment of this well-known palaeobotanic horizon to $\mathrm{Z} 2$ unit, we analysed samples from museum specimens collected historically in the Břeštany brickyard, a type locality of the so called Břeštany flora. All available specimens of the type locality of the Břeštany clay are arranged along the mixing line of smectite-poor clay assemblage and coarse clastics (Fig. 6).

The lacustrine clastics with the smectite-rich clay assemblage, zone Z3, is the thickest unit of the sediments above the main coal seam in all analysed long cores. Z3 is actually the zone with the most prominent $\mathrm{K} / \mathrm{Al}$ minima and crandallite-bearing horizons. This unit is macrofossil barren and has a remarkable lithological uniformity. The top of this unit has only been caught in HK521 core, which includes also an economically unimportant Lom coal seam at 14.4-6.9 $\mathrm{m}$ (the top part of lithofacial column in HK521, Fig. 3). At the depth 38-33 m, CEC of the sediment decreases upward perhaps due to sediment coarsening $(\mathrm{Al} / \mathrm{Si}$ also decreases upward at 42-37 m). Further sediment cores would be necessary to better define the boundary between Libkovice and Lom members.

\section{Discussion}

\section{Interpretation of key correlation horizons in Z3 unit}

The K/Al minima, some of them associated with crandallite-bearing horizons, and CEC-step horizons allow quite convincing correlation of the prevailing part of the mudstones above the main coal seams between Chomutov 


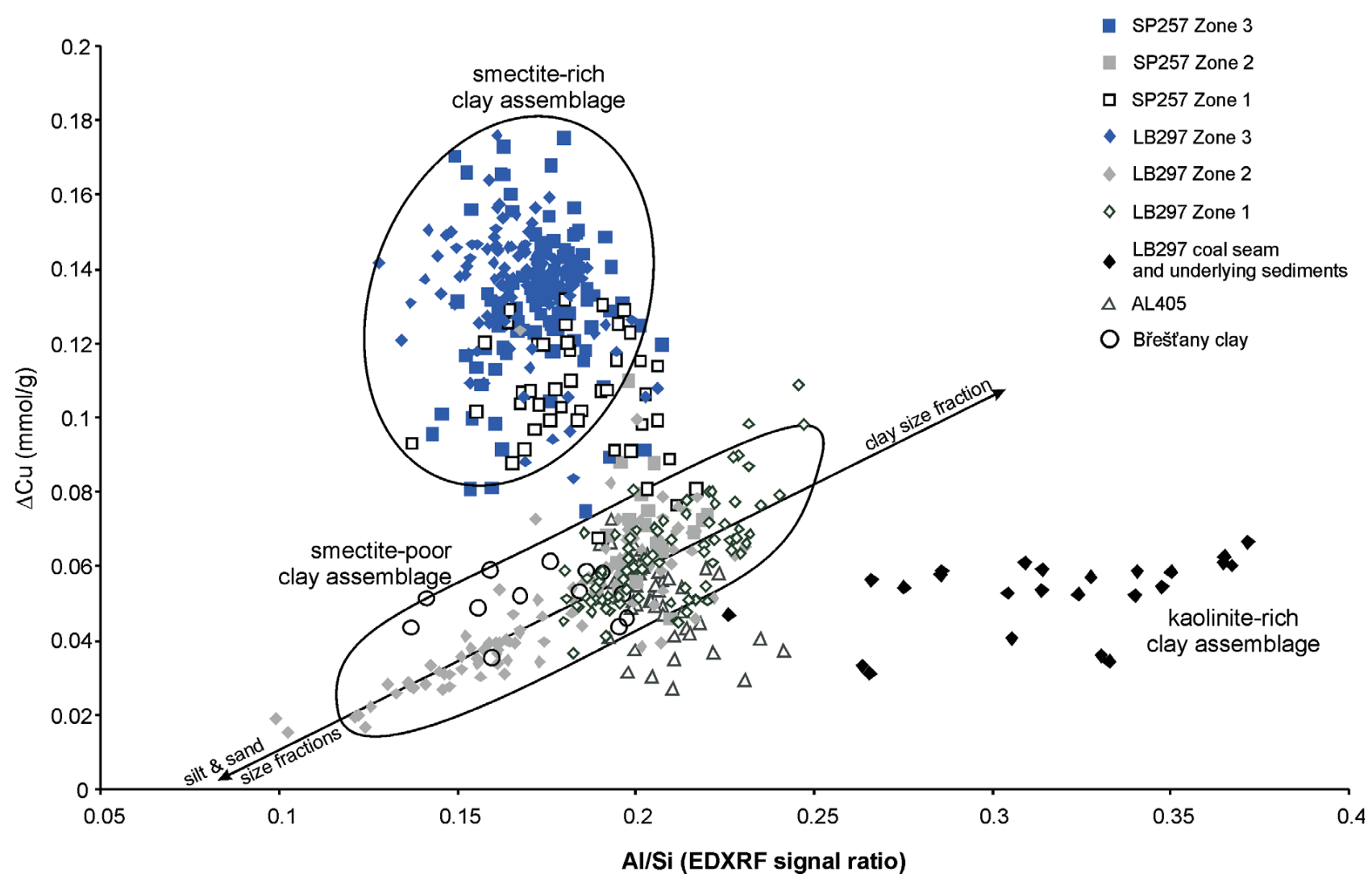

Figure 6. Plot of CEC $(\triangle \mathrm{Cu})$ and Al/Si signal ratio for sediment samples from cores LB297, AL405 and SP257 and Břeštany clay. The sediments from long cores (LB297 and SP257) were divided into zones defined in the text and Table 3.

Table 3. Sediment zones above the main coal seam according to CEC and typical lithology. Legend: $x-$ mean, $\sigma-$ standard deviation, both in mmol $\mathrm{Cu}^{2+} / \mathrm{g}$

\begin{tabular}{|c|c|c|c|}
\hline $\begin{array}{l}\text { Zone (from } \\
\text { bottom to } \\
\text { top) }\end{array}$ & $\begin{array}{l}\text { Chomutov depocentre } \\
\text { (Libouš-Droužkovice mine, } \\
\text { SP257, DO546) }\end{array}$ & $\begin{array}{l}\text { Bílina depocentre west (VČSA mine, AL405 } \\
\text { and VČSA1/2011) }\end{array}$ & $\begin{array}{l}\text { Bílina depocentre east (Bílina mine, LB297, HK521, } \\
\text { HK591) }\end{array}$ \\
\hline $\mathrm{Z3}$ & \multicolumn{3}{|c|}{$\begin{array}{l}\text { massive clays (Chomutov depocentre) or silty clays (Bílina depocentre), smectite-rich clay assemblage, } \\
\Delta \text { Cu: } \mathrm{x}=0.125, \sigma=0.018\end{array}$} \\
\hline Z2 & $\begin{array}{l}\text { smectite-rich clay assemblage } \\
\Delta \mathrm{Cu}: \mathrm{x}=0.072, \sigma=0.019\end{array}$ & & $\begin{array}{l}\text { massive or laminated clays with increased silt and sand } \\
\text { components (Bílina delta clastics), smectite-poor clay } \\
\text { assemblage, } \Delta \mathrm{Cu} \text { : } \mathrm{x}=0.060, \sigma=0.016 \text { (sandy sediments } \\
\text { excluded) }\end{array}$ \\
\hline
\end{tabular}

Z1 smectite-rich clay assemblage, (only AL405) smectite-poor clay assemblage, smectite-poor clay assemblage, $\Delta$ Cu: $\mathrm{x}=0.064, \sigma=0.014$ $\Delta \mathrm{Cu}: \mathrm{x}=0.110, \sigma=0.016 \quad \Delta \mathrm{Cu}: \mathrm{x}=0.053, \sigma=0.010$

and Bílina depocentres shown in Fig. 7. All these horizons are present in monotonous lacustrine mudstones, in the Bílina area they all are above the uppermost traces of the Bílina delta clastics. To accept them as local key horizons, their nature should be discussed to judge, what could have triggered them and whether that triggers could have been events affecting isochronously the entire basin.

The CEC-step horizon was found in the overlying clastics in all studied long cores. It is obviously coincident with the onset of "montmorillonite"-rich clay assemblage identified in the Koh-i-noor line in the Most area
(Rákosová 1982, Sloupská 1985). This horizon has hence been found in two main depocentres of the Most Basin: Bílina and Chomutov depocentres. The existence of the CEC-step horizon can offer several explanations: a change in the sediment source area, a change in the sediment sorting before deposition triggered by a change of a hydrological regime in the lake, and post-depositional mineralogical changes in clay assemblage due to acidity and/or salinity extremes. The first cause would be most straightforward and could be attributed to changes of the course of the "central river", the main tributary of the Most Basin (Mach 2010). The second possible explanation of the CEC step 


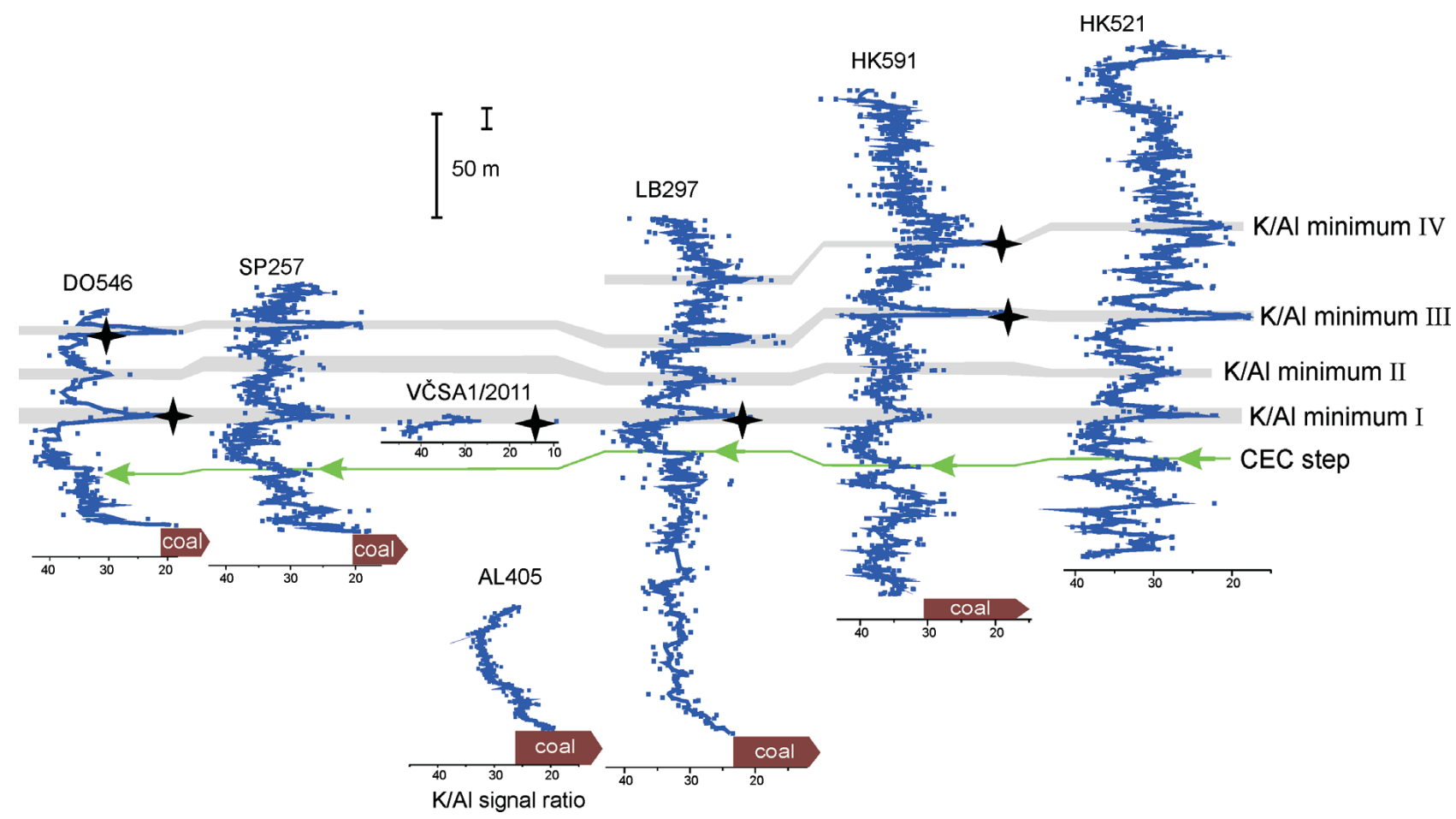

Figure 7. Comparison of $\mathrm{K} / \mathrm{Al}$ signal ratio, position of CEC-step horizon (green arrow) and crandallite-bearing horizons (C\#) for all studied cores. Legend: green arrow - the CEC-step horizon, black asterisk - crandallite-bearing horizon, grey polygons - correlation horizons of the prominent $\mathrm{K} / \mathrm{Al}$ minima, brown rectangles: position of the top of the main coal seam. Horizontal position of the cores is aligned to K/Al minimum I.

could be the sediment enrichment by smectite due to a decreased transport energy of water flow. Detritic smectites have always finer particles than detritic illite and kaolinite and hence smectites are transported farther offshore (Tucker 2001, p. 101). In our case the decrease of the transport energy could have been caused by increasing lake level. That explanation would be in agreement with the sedimentological study of the termination of the Bílina delta deposition (Rajchl et al. 2008) and with an opinion of several field geologists claiming that a relatively fast lake level increase terminated formation of coal and deposition of deltaic clastics in the entire basin (Elznic 1968, Rajchl et al. 2009, Mach 2010).

The third explanation of the CEC step could be a selective attack of expandable clay minerals in lake waters enriched in acid solutions produced by decay of thick peat strata just before the lake regression at basin scale. Large water bodies probably coexisted with extensive swamp forests and peatlands in the interval 3 of the basin development according to Rajchl et al. (2009). Laboratory studies showed experimentally that smectite is the preferentially attacked clay mineral when clastics are exposed to acid solutions (Galan et al. 1999, Martínez et al. 2007). Smectite is surely faster dissolved in aqueous solution of mineral acids than illite; it results in a continuous decrease of CEC (Pentrák et al. 2010) and amorphization (Madejová et al. 2009). Also in weaker acids (at pH 3), CEC of smectite decreases due to its partial amorphization and illitization (Bauer et al. 2001). Low $\mathrm{pH}$ of the water in the lake(s), which terminated the coal formation in the Bílina area, would be in agreement with a common presence of occasional siderite laminae or lenses in the sediments just above the coal seam. Fortunately, all these mechanisms proposed to explain the CEC-step horizon (the change in the sediment source area and changes triggered by an increase of the lake level) could really have produced an isochronous horizon or a surface very nearly isochronous. We can hence postpone the selection of the actual cause of the CEC step; it would require additional work exceeding the scope of this paper.

The K/Al variation in otherwise lithologically uniform lacustrine sediments can have two main reasons: a change in the weathering intensity ratio ( $\mathrm{K}$ is much more mobile than Al during chemical weathering under any climatic and environmental conditions) and a possible influx of volcanoclastic material to the lake, from which $\mathrm{K}$ would be quickly removed by interaction with lake water. The association of the crandallite-bearing horizons with three of four prominent K/Al minima could favour the latter explanation, because crandallite was reported to be formed by an interaction of volcanic fallouts with other sediment components (Dill 2001). We cannot clearly distinguish between these two explanations, but both changes in watershed weathering and volcanic fallout could have produced whole-basin key markers. 


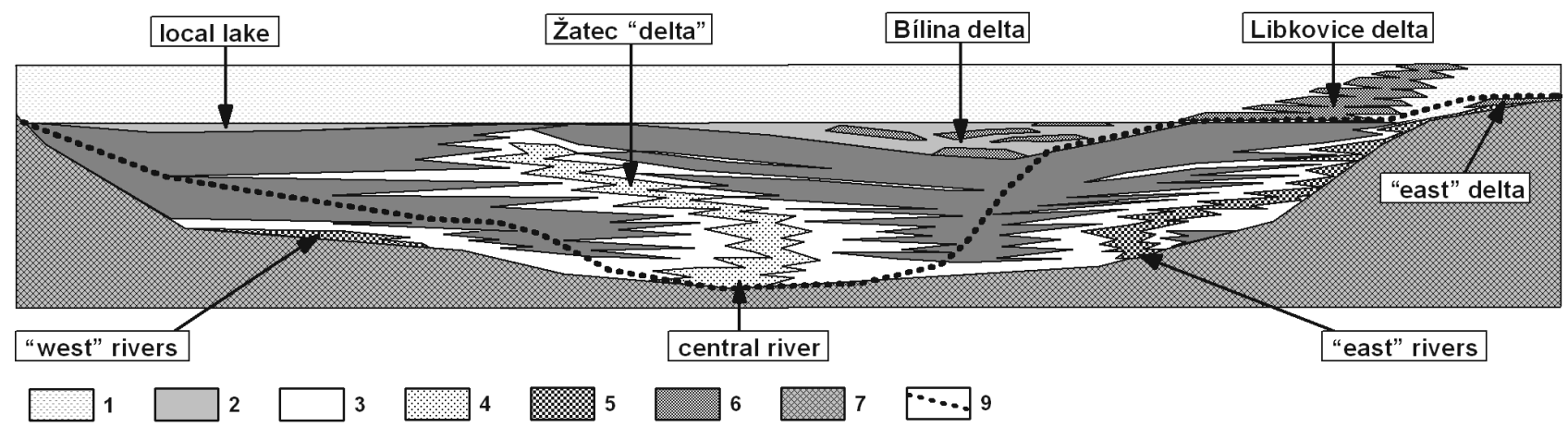

Figure 8. Idealised scheme of the Holešice Member (facies 2 to 6) with overlying facially uniform Libkovice Member (facies 1). Legend: 1 - clay sediments of Libkovice lake, 2 - clay sediments of local lakes and prodeltaic sediments, 3 - clay sediments of alluvial plains, 4 - sandy to gravel sediments of the "central river" (channel fills, crevasse splays and levees), 5 - sandy or clay conglomerates of local rivers, 6 - sandy sediments of delta bodies, 7 - pre-Miocene basement, 8 - boundary of upper and lower geochemical complexes sensu Elznic et al. (1998).

\section{Previous ways to stratigraphy of Most Formation}

Nearly all previous stratigraphic systems for the Miocene fill of the Most Basin were based only on local lithostratigraphy. Up to now, three attempts have been done to establish chronostratigraphic frame for the basin fill and to align variable lithostratigraphy in individual parts of the basin: magnetostratigraphic analysis, geochemical analysis and basin-scale correlation of the main coal seam.

Magnetostratigraphic analysis by Bucha et al. (1987) was an attempt to establish a chronostratigraphy for the entire Miocene fill of the Most Basin. That work would, however, require confirmation by tools fulfilling present-day standards of rock magnetic studies, in particular a conventional stepwise demagnetization and robust statistic evaluation to isolate the original palaeomagnetic signal. Rajchl et al. (2009) pointed out to the occurrence of unconformities in the sediment fill in the Most area, where the drill cores for the study by Bucha et al. were taken. Any unidentified unconformity would make a fit of the measured magnetostratigraphic logs with the reference curve arbitrary. Last but not least, magnetostratigraphic dating of a sediment sequence is usually initiated by at least one independent dating point (e.g., a detailed biostratigraphic zone) to start alignment of the experimentally obtained chronozones to a reference curve; such a dating point is still not available for the sediment fill in the Most Formation.

Čadek, Dušek and Elznic (Čadek et al. 1987, Elznic et al. 1998) found a horizon in the Holešice Member of the Most Formation, at which there is a relatively sharp change of the element geochemistry and mineralogy of the clastics. Main local material strongly influenced by a weathering crust of Oligocene volcanics, has increased Ti, $\mathrm{Sr}$, and $\mathrm{Zr}$ concentrations and kaolinite as the prevailing clay mineral and its deposits are locally highly variable. Contrarily, the clastics transported to the basin by the "central river" from more remote areas (Palaeozoic to Cre- taceous deposits mainly from SW part of the Bohemian Massif) have larger contents of $\mathrm{K}$ and other alkali metals, considerably more illite and smectite in the clay assemblage, and their deposits are much more spatially uniform. Elznic et al. (1998) denoted these two types of clastics "older sediments complex" (the Duchcov Member in the entire basin, a part of the Holešice Member in the central part and the entire Holešice Member in the eastern part of the basin) and "younger sediment complex" (a part of the Holešice Member and the Libkovice Member in the entire basin). Their boundary is easily recognized also in Figs 3, 4 and 5 as a switch between lower (Ti-rich) and upper (K-rich) sediments and it is depicted as a thick broken line in Fig. 8. Elznic et al. (1998) assumed that the switch between "older" and "younger" clastics was an isochronous event in the entire basin. On that basis the authors concluded that the coal-forming swamp "travelled" across the basin from SW to NE. This idea is in the contradiction with the third attempt to find key bed markers in the Most Basin fill: the correlation of the clastic horizons in the main coal seam (Mach 1997). These clastic horizons were deposited by alluvial systems of the "central river" passing through the basin or by local streams terminated in the basin. These rivers supplied water and clastics to large areas of flat peatlands; each avulsion produced a novel extensive system of meandering or braiding channels accompanied by deposition of crevasse splay deposits, which can be traced over long distances along each channel belt. One of such alluvial system of the "central river" was studied in details by Rajchl \& Uličný (2005). These studies showed that the main coal seam can be divided to sub-layers correlatable within the whole basin area (Mach 1997). In other words, the coal-forming peatland was spatially stable at the main part of the coal-forming interval, while the alluvial systems and local lakes "travelled" across the basin (Mach 2010). The "younger clastics" are thickest in the areas impacted by the "central river" and thinnest in the areas mostly affected by local streams (Fig. 8). 


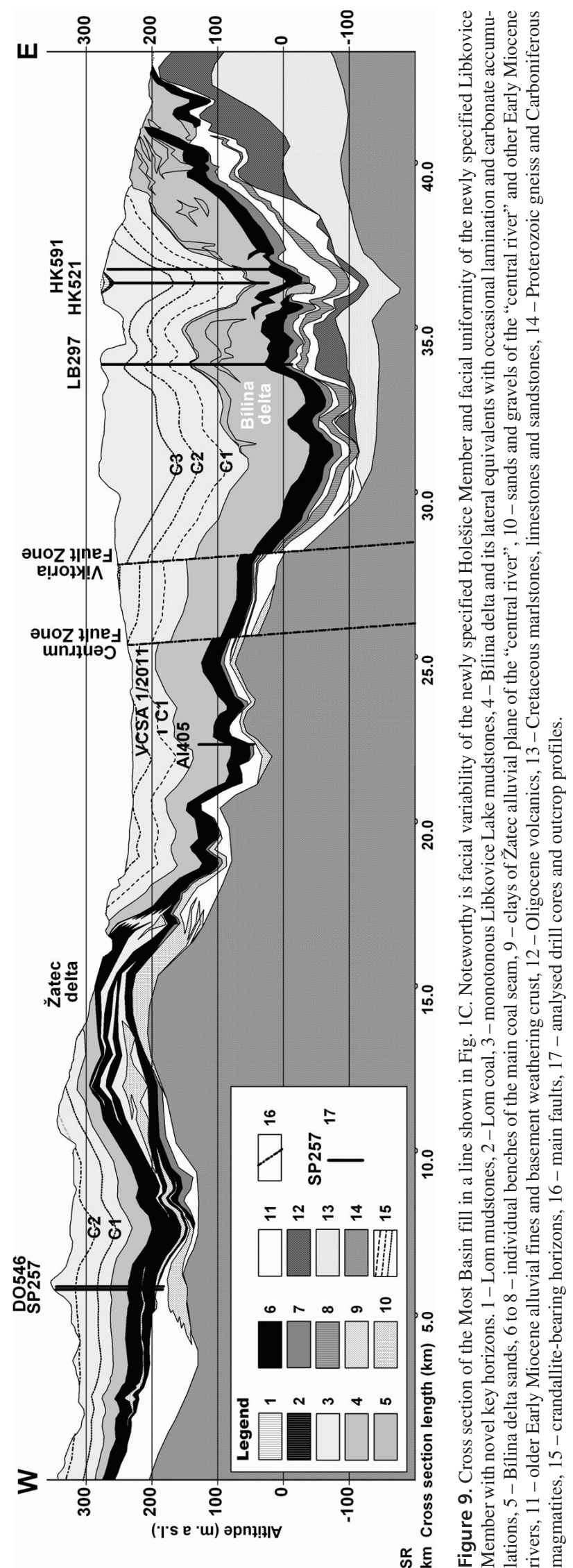

Our presented work demonstrates that the dominant part of the lacustrine mudstones above the main coal seam was deposited in a single lake covering at least the Chomutov and Bílina depocentres of the Most Basin and the area between them. It is noteworthy that in the palaeogeographic model of the basin development by Elznic et al. (1998) there is no time slice, which would depict a single water body in both these two depocentres. The reconstruction by Elznic et al. (1998) is based on the assumption of an event-like palaeogeographic change in the entire basin during the interval 3 of the basin development according to Rajchl et al. (2009), i.e. in the interval of variable facies existing side by side before the final enhancement of the basin subsidence. We consider more reliable to start the basin-scale correlation in a "top-down" direction, i.e. from the stage of the spatially most extensive lake, i.e. from the interval 4 of the basin development according to Rajchl et al. (2009).

\section{Contribution to stratigraphy of Most Formation}

A cross section through the Most Basin fill with newly specified boundary of Holešice and Libkovice members and key horizons in the latter is shown in Fig. 9. It correlates the Libkovice lake sediments from the eastern part of the Bílina depocentre to the Chomutov depocentre. The switch between "older" and "younger" clastics, considered to be isochronous by Elznic et al. (1998), crosses the Holešice Member according to the palaeogeographic situation in the basin (Fig. 8). The switch is situated deeper in the areas earlier flooded by water with clastics from the "central river", e.g. in the Chomutov depocentre and in VČSA mine (left side of Fig. 8).

We propose to consider zone $\mathrm{Z3}$ described in this paper as an equivalent of the Libkovice Member of the Most Formation. These sediments are apparently monotonous lacustrine mudstones, mainly composed of K-rich clastics with smectite-rich clay assemblage and deposited in a unique, large, probably a whole-basin lake. Although mineralogical and elemental composition of these sediments have previously been considered too uniform for further differentiation (Čadek et al. 1987, Elznic et al. 1998), we found in them characteristic depth profiles of K/Al and up to three crandallite-bearing horizons, which allow their basin-scale correlation. The lower boundary of the Libkovice Member would then be defined by an increase of the cation exchange capacity due to an increased fraction of smectite structures in the clay assemblage (black arrows in Figs 3 and 4 and green arrows in Fig. 7). The upper boundary could preliminarily be defined by the decrease of the cation exchange capacity and $\mathrm{Al} / \mathrm{Si}$ ratio attributed - on the base of previous studies - to temporary lake shalowing and consequent sediment coarsening with subsequent formation of 
the Lom coal seam (Elznic 1968, Domácí 1975, Váně 1987). So defined sediment zone $Z 3$ is close to the original lithological definitions of the Mariánské Radčice Formation by Elznic (1968) and Libkovice Member by Domácí (1975) and Váně (1987). We newly propose quantitative (numeric) definitions for these sediments (Table 3 and Fig. 6) and show their correlation between Chomutov and Bílina depocentres (Figs 1 and 7), which was yet missing. Our concept of Holešice and Libkovice members fully respects facial variability of Holešice Member, the basin fill in the early stages of the basin subsidence - it was not addressed in the former lithostratigraphic systems.

The use of the CEC-step horizon as the lower boundary of the Libkovice Member would assign the Břrštany clay, well-known facies from the Bílina area (Kvaček 1998, Kvaček et al. 2004, Kvaček \& Teodoridis 2007, Teodoridis 2010) to the top of the Holešice Member. Břeštany clays are probably fine lateral equivalents of the Bílina delta immediately before the definitive increase of the lake level towards the basin-scale lake or during that transgression (Rajchl et al. 2009). Up to now the Břeštany clay has been assigned to Libkovice Member (Kvaček et al. 2004, Kvaček \& Teodoridis 2007, Teodoridis \& Kvaček 2006, Teodoridis 2010), although Mach (2003) and Rajchl et al. (2008) proved that Bílina delta brought clastics into the peatland, i.e. these clastics are lateral equivalents of the Holešice coal seam. Our proposal would also allow extending the upper boundary of the Holešice Member to the Chomutov depocentre using the CEC-step horizon as a local key correlation marker. This would assign the so-called micaceous facies (Kvaček \& Teodoridis 2007, Teodoridis 2010), fossiliferous sediments just above the main coal seam at the Krušné Hory Mts edge, to be deposited isochronously with the uppermost part of the Holešice Member in the Bílina depocentre before the whole-basin Libkovice lake stage. Our findings and a new definition of the Holešice and Libkovice members can have relevance for the evaluation of palaeoenvironmental reconstructions made recently by Teodoridis (2010) and Teodoridis et al. (2011). Teodoridis et al. reconstructed higher mean annual temperatures from Břeštany flora than other floras from the Most Basin, mainly from sediments close to the top of the coal seam, although they probably all belongs to the top of the Holešice Member.

Our results are in agreement with the idea that the top of the Holešice Member should also include non-coal lateral equivalents, such as fluvial clastics from rivers, which fed the extensive peatlands by water including proximal and distal delta facies in local water bodies. This idea is well substantiated by sedimentological studies (Mach 2003, Rajchl et al. 2008). In fact a facial variability of the Most Basin during the coal formation has been assumed by local geologists many years ago (Hokr 1982, Elznic et al. 1998 and references therein), but we now propose to really adopt it into lithostratigraphic schemes of the Most Basin by two means: by including all facies coeval with coal formation to the Holešice Member (Fig. 8) and by defining the boundary between Holešice and Libkovice Member as the earliest clear marker of the existence of the whole basin lake, which actually terminated the lateral facial variability (Figs 8 and 9).

\section{Outlines of further research}

This paper is a basis for current active and future planned research in the Most Basin. The results will make it possible to further improve palaeogeographic reconstruction of the basin development in the period near the termination of the coal formation (Mach 2010), which will not be based on an arbitrary assumption of an isochronous change of the sediment source area during the deposition of the Holešice Member (Elznic et al. 1998). Further work in this direction is now in progress.

A detailed analysis of the "non-crandallite-related" $\mathrm{K} / \mathrm{Al}$ variations (not shown in this paper) and $\mathrm{Sr}$ contents in the lithologically most uniform lacustrine sediments of LB297, HK521 and SP257 (zone Z3) revealed that orbital forcing by short eccentricity, obliquity and precession may be recorded in the most stable (most monotonous) lacustrine sediments in the Libkovice Member (Matys Grygar et $a l$. submitted). Milankovitch-like cyclicity is one of the most straightforward explanations of regular repetitive changes in sufficiently long sediment sequences (covering usually $10^{5}$ to $10^{6}$ years) formed under relatively stable setting; such was actually the basin-wide Libkovice lake (Matys Grygar et al. submitted). It is well known that to interpret any sediment record in terms of climate, chronostratigraphy basis and certain palaeogeographic frames for the sediment source area must first be established. The palaeoclimate reconstructions based on comparison of floras from individual sites in the Most Basin (Teodoridis 2010, Teodoridis et al. 2011) also needs to refine yet uncertain stratigraphic assignment of those sites. These goals substantiate our effort in discussing an apparently "local problem" of the Most Basin stratigraphy.

\section{Conclusions}

Element (EDXRF) and chemical (CEC) proxies were successfully used for correlation of a considerable part of the clastic sequences that overlie the main coal seam in the Most Basin. One of the subunits, Z3 was deposited in a lake covering at least Chomutov and Bílina depocentres and the area between them. Its sediments are now $80 \mathrm{~m}$ thick in the Chomutov depocentre (the Spořice and Droužkovice areas) and up to $150 \mathrm{~m}$ in the Bílina depocentre (the 
Hrdlovka area). The proxy analyses afford the reliable definition of this unit independently on the sediment actual lithology or appearance.

We newly propose to make the $\mathrm{Z} 3$ unit identical with the Libkovice Member, having been introduced in several previous lithostratigraphic systems, but up to now without any unequivocally defined boundaries. One of the main contributions of this paper is hence that we aligned some geochemical properties (CEC, $\mathrm{K} / \mathrm{Al})$ to the already defined litostratigraphic units and proposed their conversion to members with an isochronous boundary. Proxy analyses provide a basis for the stratigraphic correlation of fine lacustrine sediments from several important palaeobotanic localities in the Most Basin, which has yet been impossible. In future the newly proposed stratigraphic correlation will be useful in the establishment of a new model of palaeogeographic evolution of the basin. The plots of CEC versus $\mathrm{Al} / \mathrm{Si}$ ratio is a efficient tool for fingerprinting siliciclastic sediments with a variable clay mineral assemblage, based on routine chemical laboratory analyses by simple means.

\section{Acknowledgment}

The samples from drill cores were obtained from Severočeské doly, a.s. (North Bohemian Coal Mines, s.a.) and Litvínovská uhelná, a.s. (Litvínov Coal company, s.a.). Samples of Břeštany clays were obtained from paleontological collections of Regional Museum Most, Regional Museum Teplice and Senckenberg Naturhistorischen Sammlungen Dresden thanks to Pavel Dvořák, Miroslav Radoň and Lutz Kunzmann. Laboratory analyses were performed thanks to support by the Czech Science Foundation (P210/11/1357) and institutional support for the Institute of Inorganic Chemistry AS CR, v.v.i. (AV0Z40320502). Sample handling and analyses in the Institute of Inorganic Chemistry AS CR, v.v.i. were performed by Jana Dörfová, Zuzana Hájková and Petr Vorm. The authors thank to Zdeněk Dvořák and Pavel Coufal (Severočeské doly) and Vasilis Teodoridis (Faculty of Education, Charles University, Prague) for fruitful discussions. Tereza Nováková (Faculty of Science, Charles University, Prague) helped with formatting the manuscript. The authors thank to Lluís Cabrera and an anonymous reviewer, who helped considerably to improve the manuscript.

\section{References}

Bauer, A., Schafer, T., Dohrmann, R., Hoffmann, H. \& Kim, J.I. 2001. Smectite stability in acid salt solutions and the fate of $\mathrm{Eu}$, Th and U in solution. Clay Minerals 36, 93-103. DOI 10.1180/000985501547376

Bucha, V., Elznic, A., Horáček, J., Malkovský, M \& PazderKOVÁ, A. 1987. Paleomagnetic timing of the Tertiary of the North Bohemian Brown-Coal Basin. Věstník Ústředního ústavu geologického 62, 83-95.
ČADEK, J., DušEK, P. \& Elznic, A. 1987. Geochemie sedimentů severočeské pánve. Internal report, Ústřední ústav geologický, Prague.

Coufal, P. \& MejstříkovÁ, L. 1996. Unikátní barium-stronciová mineralizace na lokalitách DNT. Hnědé uhlí 1(96), 41-50.

DiLl, H.A. 2001. The geology of aluminium phosphates and sulphates of the alunite group minerals: a review. Earth-Science Reviews 53, 35-93.

DOI 10.1016/S0012-8252(00)00035-0

DoMÁCí, L. 1975. Litostratigrafie třetihorních sedimentů v hnědouhelné severočeské pánvi. Acta Universitatis Carolinae, Geologica 1, 75-80.

DvořÁ, Z. \& МАCH, K. 1999. Deltaic deposits in the North Bohemian Brown Coal Basin and their documentation in the Bílina opencast mine. Acta Universitatis Carolinae 4, 633-641.

ElZNIC, A. 1968. Příspěvek k problematice stratigrafického členění miocenních sedimentů severočeské hnědouhelné pánve a k uhlonosnosti jednotlivých souvrství, 1-21. In SEVEROČESKÉ UHELNÉ DOLY (ed.) Technicko-ekonomický zpravodaj. Zetaprinton, Most.

ElzNIC, A. 1973. Sedimenty neogénu a vývoj uhelné sloje v mostecké části severočeské pánve. Sborník geologických věd, Geologie 24, 175-204.

Elznic, A., ČADKovÁ, Z. \& DušEK, P. 1998. Palaeogeography of Tertiary sediments of North Bohemian Basin. Sborník geologických věd 48, 19-46.

Galan, E., Carretero, M.I. \& Fernandez-Caliani, J.C. 1999. Effects of acid mine drainage on clay minerals suspended in the Tinto River (Río Tinto, Spain). An experimental approach. Clay Minerals 34, 99-108. DOI 10.1180/000985599546118

Grygar, T., Kadlec, J., Žigová, A., Mihaljevič, M., Nekutová, T., LOJKA, R. \& SvĚTLÍK, I. 2009. Chemostratigraphic correlation of sediments containing expandable clay minerals based on ion exchange with $\mathrm{Cu}$ (II) complex with triethylenetetramine. Clays and Clay Minerals 57, 168-182.

DOI 10.1346/CCMN.2009.0570204

Grygar, T., Světlík, I., Lisá, L., Koptíková, L., Bajer, A., Wray, D.S., Ettler, V., Mihaljevič, M., Nováková, T., Koubová, M., Novák, J., MáčKa, Z. \& Smetana, M. 2010. Geochemical tools for the stratigraphic correlation of floodplain deposits of the Morava River in Strážnické Pomoraví, Czech Republic from the last millennium. Catena 80, 106-121. DOI 10.1016/j.catena.2009.09.005

HoKr, Z. 1982. Redefinice mosteckého souvrství (miocén, severočeská hnědouhelná pánev). Sborník IV. uhelné geologické konference, Př́rodovědecká fakulta Univerzity Karlovy, Praha, 47-52.

HuRNí, S. 1978. Rekonstrukce mocnosti nadložního souvrství v severočeské hnědouhelné pánvi (miocén). Časopis pro mineralogii a geologii 23, 265-276.

HuRník, S. 2001. Zavátá minulost Mostecka. Sborník Okresního muzea v Mostě 23, 1-139.

HuRní, S. \& MAREK, D. 1962. Ke stratigrafii severočeského terciéru na východ od Doupovských hor. Časopis pro mineralogii a geologii 1, 35-41.

KOPECKÝ, L. 1978. Neoidic taphrogenic evolution and young alkaline volcanism of the Bohemian Massif. Sborník geologických věd, Geologie 31, 91-104. 
KvAČEK, Z. 1998. Bílina: a window on Early Miocene marshland environments. Review of Palaeobotany and Palynology 101, 111-123. DOI 10.1016/S0034-6667(97)00072-9

KvaČek, Z., BöHme, M., Dvořák, Z., KonZalová, M., Mach, K., SAKALA, J. \& RAJCHL, M. 2004. Early Miocene freshwater and swamp ecosystems of the Most Basin (northern Bohemia) with particular reference to the Bílina Mine section. Journal of Czech Geological Society 49, 1-40.

KvaČEK, Z. \& TEODORIDIS, V. 2007. Tertiary macrofloras of the Bohemian Massif: a review with correlations within Boreal and Central Europe. Bulletin of Geosciences 82(4), 383-408. DOI 10.3140/bull.geosci.2007.04.383

Lojka, R., Drábková, J., Zajíc, J., SÝkorová, I., Francư, J., BláhovÁ, A. \& Grygar, T. 2009. Climate variability in the Stephanian B based on environmental record of the Mšec Lake deposits (Kladno-Rakovník Basin, Czech Republic). Palaeogeography, Palaeoclimatology, Palaeoecology 280, 78-93. DOI 10.1016/j.palaeo.2009.06.001

MACH, K. 1997. A loging correlation scheme for the Main coal seam of the North Bohemian brown coal basin, and the implications for the palaeogeographical development of the basin, 309-320. In GAYER, R. \& PEŠEK, J. (eds) European Coal Geology and Technology. Geological Society of London, Special Publication No. 125.

MACH, K. 2003. Geologické aspekty výskytu pevných poloh na povrchovém lomu Bílina. Zpravodaj Hnědé uhlí 3, 55-63.

MACH, K. 2010. A new concept of palaeogeographic development of the Most basin area during Miocene, 313. In HopPE, A., Röhling, H.G. \& SchüTH, C. (eds) GeoDarmstadt 2010 $8^{\text {th }}$ European Coal Conference, Darmstadt, 10-13 October 2010, SDGG Publication 68.

MACH, K., ŽÁK, K. \& JAČKOVÁ, I. 1999. Zastoupení a izotopové složení jednotlivých forem síry ve vertikálním profilu hlavní uhelné sloje v severočeské hnědouhelné pánvi a jejich paleogeografický význam. Věstník Českého geologického ústavu 74, 51-66.

Madejová, J., Pentrák, M., Palková, H. \& Komadel, P. 2009. Near-infrared spectroscopy: A powerful tool in studies of acid-treated clay minerals. Vibrational Spectroscopy 49, 211-218. DOI 10.1016/j.vibspec.2008.08.001

Malkovský, M. (ed.) 1985. Geology of North Bohemian Browncoal Basin and its Surroundings. 424 pp. Ústřední ústav geologický, Academia, Prague. [in Czech]

Martínez, J.A., Jiménez de Cisneros, C. \& Caballero, E. 2007. Natural acid sulphate alteration in bentonites (Cabo de Gata, Almeria, SE Spain). Clay Minerals 42, 89-107.

DOI 10.1180/claymin.2007.042.1.07

Matys Grygar, T., Mach, K., Laurin, J. \& Koubová, M. Submitted. Chemostratigraphy and orbital forcing in Early Miocene lacustrine deposits of Eger Graben in Czech Republic (Lake Libkovice, Most Basin). International Journal of Earth Sciences.

Meier, L.P. \& Kahr, P. 1999. Determination of the cation exchange capacity (CEC) of clay minerals using the complexes of copper (II) ion with triethylenetetranine and tetraethylenepentamine. Clays and Clay Minerals 47, 386-388. DOI 10.1346/CCMN.1999.0470315

Nichols, G. 1999. Sedimentology and Stratigraphy. 263 pp. Blackwell Publishing.
Novák, F., Pekárková, R. \& Ševcư, J. 1993. Barium rich crandallite from the Nástup Tušimice quarry (North-Bohemian Brown-Coal Basin). Věstník Českého geologického ústavu 68, 53-57. [in Czech]

PARRISH, J.T. 1998. Interpreting Pre-Quaternary Climate from the Geologic Record. 338 pp. Columbia University Press, New York.

Pentrák, M., Madejová, J. \& Komadel, P. 2010. Effect of chemical composition and swelling on acid dissolution of 2:1 clay minerals. Philosophical Magazine 90, 2387-2397. DOI 10.1080/14786430903559433

PEŠEK, J. et al. 2010. Terciérní pánve a ložiska hnědého uhlí České republiky. 438 pp. Czech Geological Survey, Prague.

PEŠEK, J. \& SPUDIL, J. 1986. Paleogeografie středočeského a západočeského neogénu. (Paleogeography of the Neogene of central and western Bohemia). Studie ČSAV, 1-79.

RAJChl, M. \& UliČNÝ, D. 2005. Depositional record of an avulsive fluvial system controlled by peat compaction (Neogene, Most Basin, Czech Republic). Sedimentology 52, 601-625. DOI 10.1111/j.1365-3091.2005.00691.x

RajChl, M., UličnÝ, D., Grygar, R. \& MaCh, K. 2009. Evolution of basin architecture in an incipient continental rift: the Cenozoic Most Basin, Eger Graben (Central Europe). Basin Research 21, 269-294.

DOI 10.1111/j.1365-2117.2008.00393.x

RAJCHL, M., ULIČNÝ, D. \& MACH, K. 2008. Interplay between tectonics and compaction in a rift-margin, lacustrine delta system: Miocene of the Eger Graben, Czech Republic. Sedimentology 55, 1419-1447.

DOI 10.1111/j.1365-3091.2008.00951.x

RÁKosovÁ, M. 1982. Jílové minerály v tercierních sedimentech SHR (V. linie vrtů budoucího velkolomu Kohinoor). Zpravodaj Výzkumného ústavu hnědého uhlí 1-2, 27-37.

SLOUPSKÁ, M. 1985. Nerostné složení tercierních sedimentů SHR. Internal report, Výzkumný ústav hnědého uhlí, Most.

TeOdoridis, V. 2010. The Integrated Plant Record vegetation analysis of Early Miocene assemblages from the Most Basin (Czech Republic). Neues Jahrbuch für Geologie und Paläontologie, Abhandlungen 256(3), 303-316.

DOI 10.1127/0077-7749/2010/0055

TeOdoridis, V. \& KvačEK, Z. 2006. Palaeobotanical research of the Early Miocene deposits overlying the main coal seam (Libkovice and Lom Members) in the Most Basin (Czech Republic). Bulletin of Geosciences 81(2), 93-113.

DOI 10.3140/bull.geosci.2006.02.093

Teodoridis, V., Mazouch, P., Siter, R.A. \& Uhl, D. 2011. Refining CLAMP - Instigations towards improving the Climate Leaf Analysis Multivariate Program. Palaeogeography, Palaeoclimatology, Palaeoecology 299, 39-48.

DOI 10.1016/j.palaeo.2010.10.031

TuCKer, M.E. 2001. Sedimentary Petrology. An Introduction to the Origin of Sedimentary Rocks. 272 pp. Blackwell Science, Oxford \& Boston.

VÁNĚ, M. 1987. Návrh nového stratigrafického dělení severočeského terciéru. Geologický průzkum 1/1987, 9-11.

ZiEgLER, P.A. \& Dèzes, P. 2007. Cenozoic uplift of Variscan Massifs in the Alpine foreland: Timing and controlling mechanisms. Global Planet Change 58, 237-269. 